\title{
A new bread formulation based on a partial substitution of soursop residues flour through Mixolab and a process mixture design
}

\author{
Annel SAAVEDRA ${ }^{1}$, Dominique ALMENDARIZ ${ }^{1}$, Danny NAVARRETE¹, María Gabriela VERNAZA ${ }^{1 *}$
}

\begin{abstract}
Ecuador has one of the highest soursop productions worldwide; however, as this fruit represents a promising market to the country, its organic waste is becoming a major problem. The aim of the study was to use the Mixolab to predict the quality of wheat flour partially substituted by soursop residues flour for bread making. The experiment was performed through a process mixture design; 21 premixes were made, and 10 significant variables were chosen. Using a desirability function, three criteria were optimized: 1) to maximize the use of soursop residues flour (SRF) (20\% SRF substitution), 2) to form a loaf with strong gluten network characteristics ( $5 \%$ SRF substitution), and 3) to form a loaf with weak gluten network characteristics (13.2\% SRF substitution). Results showed with a 95\% confidence level that the new formulation with strong gluten network characteristics, $5 \%$ soursop residue flour and $95 \%$ wheat flour, was statistically equal to a control bread in moisture, $\mathrm{pH}$ and total ashes content. Additionally, an affective test was performed in order to identify the acceptability of the bread among potential consumers.
\end{abstract}

Keywords: bread production; sustainability; design of experiments; agro-industrial waste.

Practical Application: Juice brands all over the world are producing fruit wastes. This study was performed to determine if the flour made from soursop residues could be used for breadmaking. It was found that the wheat flour could be substituted only partially with the soursop residues flour due to the lack of gluten properties in the soursop. This work provides an idea for the reutilization of soursop residues in functional foods, it adds value to the waste and could be an opportunity to create a new product.

\section{Introduction}

Globally, 20\% of fruits and vegetables produced are lost (United Nations, 2020). To reduce the side effects of fruit wastes, such as emissions of methane and carbon dioxide, there is a need to find new ways to add value to the waste (Deng et al., 2012). Fruit waste is inexpensive, cost effective, ready for use and minimizes the environmental impact (Deng et al., 2012). For this reason, an alternative is to develop new functional food products from it, such as bread (Ferreira et al., 2015). Bread can be an alternative because the flour produced from the residues is viable for storage and can be used as a raw material in breadmaking (Ferreira et al., 2015). The importance relies on the fact that bread is a food product that is part of people's daily life, and it is one of the most important sources of carbohydrates in the food pyramid (Ibrahim et al., 2015). A way to improve bread is to enrich its functional and natural components, which can provide benefits to the health of those who consume it (Dziki et al., 2014). For instance, in Ecuador, local producers studied the effect of adding Andean Blueberry in the quality of bread and the results showed it had healthier properties due to the antioxidant content of the fruit (Guijarro-Fuertes et al., 2019). Another study showed that enriching cheese bread with cowpea resulted in being a great source of calcium, phosphorous and magnesium (Cavalcante et al., 2019).
Bread improvers are commonly added when existing variations within the breadmaking process such as substitution of ingredients. The choice of improver type depends mainly on the bread variant that is being produced or replaced (Cauvain, 2015), for example, studies have shown that glucose oxidase has good results in crumb strength but not in dough strength (Kouassi-Koffi et al., 2019) and also the enzyme can be related with the stability of the dough and with the weakening of the proteins (Tasiguano et al., 2019). Other examples of improvers are gums and enzymes like: Veron CP, which is a cellulolytic enzyme with hemicellulose that is used for treating flours, and guar gum, which is a seed galactomannan that can serve as a source of soluble dietary fiber (Mudgil et al., 2014).

The soursop fruit (Annona muricata L.) or guanábana in Spanish, grows mainly in Caribbean countries and in the tropical regions of South America: Colombia, Brazil and Ecuador (Chaparro et al., 2014). In Ecuador, most of the soursop crops are located in subtropical areas, mainly in the province of Guayas, Manabí and Santo Domingo de los Tsáchilas (Instituto Nacional de Investigaciones Agropecuarias, 2014). In the last few years, Ecuador has become one of the countries with the highest development of soursop crops because of the attractive production price in the market (Instituto Nacional de Investigaciones Agropecuarias, 2014). However, as the production 
of fruits and other foods increases, so does the generation of solid wastes (Instituto Nacional de Estadísticas y Censos, 2014). According to the Instituto Nacional de Estadísticas y Censos (2014), the amount of solid waste per day was around 11,203.24 tons, where $53.81 \%$ belonged to organic waste. Therefore, the utilization of waste could be an alternative for nutritional and functional food products; as well as a main factor to minimize waste production (Ferreira et al., 2015).

The soursop fruit consists of $67.5 \%$ edible pulp, $20 \%$ peel, $8.5 \%$ seeds, and $4 \%$ core by weight. A 100 g portion of soursop has: $81.16 \mathrm{~g}$ of water, $1 \mathrm{~g}$ of protein, $0.3 \mathrm{~g}$ of fat, $3.3 \mathrm{~g}$ of fiber and $13.54 \mathrm{~g}$ of sugars (U.S. Department of Agriculture, 2019). The extraction of soursop pulp recoveries from 62 to $82.5 \%$ (Badrie \& Schauss, 2010); the peel and seeds are removed and discarded most of the time as waste material (Lee et al., 2016).

Soursop has been widely studied in the last decade due to its organoleptic characteristics and therapeutic potential (SolísFuentes et al., 2011). The plant presents around 212 bioactive compounds (the most important being alkaloids, phenols and other compounds) and more than 120 acetogenins and 37 phenolic compounds (Coria-Téllez et al., 2018). For instance, in Brazil, because of the properties of this fruit, a nutritional profile of soursop whey beverages showed that it had benefits such as the increase of phenolic compounds, but also had negative effects such as the production of many volatile compounds (Guimarães et al., 2019). In regards to the soursop residues, the peel of the soursop contains antileishmanial activity, thus it could be used as an inexpensive source for nutraceutical ingredients (Lee et al., 2016). Soursop fruit pulp is suitable for processed products because of its high pulp recovery, flavor compounds, high sugar contents (Badrie \& Schauss, 2010), as well as, vitamins, acetogenins and carotenoids (Coria-Téllez et al., 2018). The production of flour and bakery products with soursop has been studied and has resulted in high fiber content and reasonable consumer acceptance (Ferreira et al., 2015; Ramírez \& De Delahaye, 2009; Villela et al., 2013).

The literature has only shown the use of central composite designs for partial substitutions of wheat flour in bread making. However, mixture designs are widely used in the food industry for obtaining desirable product properties by mixing different ingredients (Cornell, 2002) and for the study of the composition of the components and the effect in the response variable. A mixture experimental design is a special type of statistical approach to determine the individual effects and interaction of components in a mixture (Homkhiew et al., 2014). In addition to the mixture components in the experiment, process factors can be included which are known as process mixture design. The mathematical model is given by the properties of the linear and nonlinear blendings, and the effect of the process variables in the linear and nonlinear properties (Myers et al., 2016).

To the authors' knowledge, there are no studies regarding the use of soursop residues to make flour for the bread making process in the literature. The aim of the present study was to use the Mixolab to predict the quality of wheat flour partially substituted by soursop residues flour for bread production through a process mixture design.

\section{Materials and methods}

\subsection{Materials}

The soursop residues were donated by Proalva, a pulp fruit factory (Quito, Ecuador). The wheat flour used was Paniplus Normal (Moderna Alimentos, Quito, Ecuador) with the following specifications: moisture was $13.6 \%$ of moisture, $0.72 \%$ ash; $36.5 \%, 12.1 \%$ and $94 \%$ wet gluten, dry gluten and index gluten, respectively; and 345 seconds Falling Number. The dough improvers used were the enzyme VERON CP (AB Enzymes, Postfach, Germany) and guar gum.

\subsection{Methods}

Soursop Residues Flour (SRF)

Soursop residues were considered the squeezed pulp, seeds and peel leftovers after the extraction of the fruit juice. They were refrigerated at $7^{\circ} \mathrm{C}$ for 12 hours prior to the classification process. During the classification process, seeds and other residues were removed manually. After this, only the pulp residues were dried for 12 hours at $50{ }^{\circ} \mathrm{C}$, then they were ground in the windmill High Speed Multi-Function Comminutor (CGOLDENWALL, Zhejiang, China) to obtain the soursop residues flour.

\section{Experimental design}

For establishing the premixes, a process mixture design was used, using an I-optimal design with a second order model, resulting in 21 runs (Table 1). The mixture variables used in this research project were: $A=$ wheat flour $(80-95 \%)$ and $\mathrm{B}=$ soursop residues flour (5-20\%). Meanwhile, the process variables used were $\mathrm{C}=$ guar gum $(0.05-0.25 \%)$ and $\mathrm{D}=$ Veron CP (0.01-0.2 gr/kg).

\section{Mixolab measurements}

Through the Mixolab, following the Chopin Standard protocol, the parameters evaluated were: 1) Water absorption (WA) [\%]: quantity of water required to obtain C1,2) Amplitude [min]: the width of the curve at $\mathrm{C} 1$ or dough elasticity, 3) Dough Development time (DDT) [min]: time required to obtain $\mathrm{C} 1$, 4) Stability [min]: dough resistance to kneading, 5) $\mathrm{C} 1[\mathrm{Nm}]$ : during mixing is the maximum torque, 6) C2 [Nm]: the torque that measures the protein weakening, 7) $\mathrm{C} 3[\mathrm{Nm}]$ : the torque that measures the starch gelatinization, 8) $\mathrm{C} 4[\mathrm{Nm}]$ : the torque that measures the stability of the hot formed gel, 9) C5 [Nm]: the torque that measures the starch retrogradation during the cooling period, 10) $\mathrm{C} 1-\mathrm{C} 2[\mathrm{Nm}]$ : the strength of protein network at increasing heating, 11) $\mathrm{C} 2-\mathrm{C} 3[\mathrm{Nm}]$ : the rate of the starch gelatinization, 12) C3-C4 [Nm]: the amylase activity, 13) C4-C5 $[\mathrm{Nm}]$ : the rate of the starch retrogradation, 14) Slope alpha: the speed at which the protein weakens due to heat, 15) Slope beta: the speed of starch gelatinization, and 16) Slope gamma: the speed at which the enzymatic degradation occurs.

\section{Optimization}

To optimize the selected response variables used in the process mixture design, a simultaneous optimization technique was used. 
Table 1. Process Mixture Design (I-Optimal) with two mixture variables: wheat flour (WF) and soursop residues flour (SRF), and two process variables: guar gum and Veron CP.

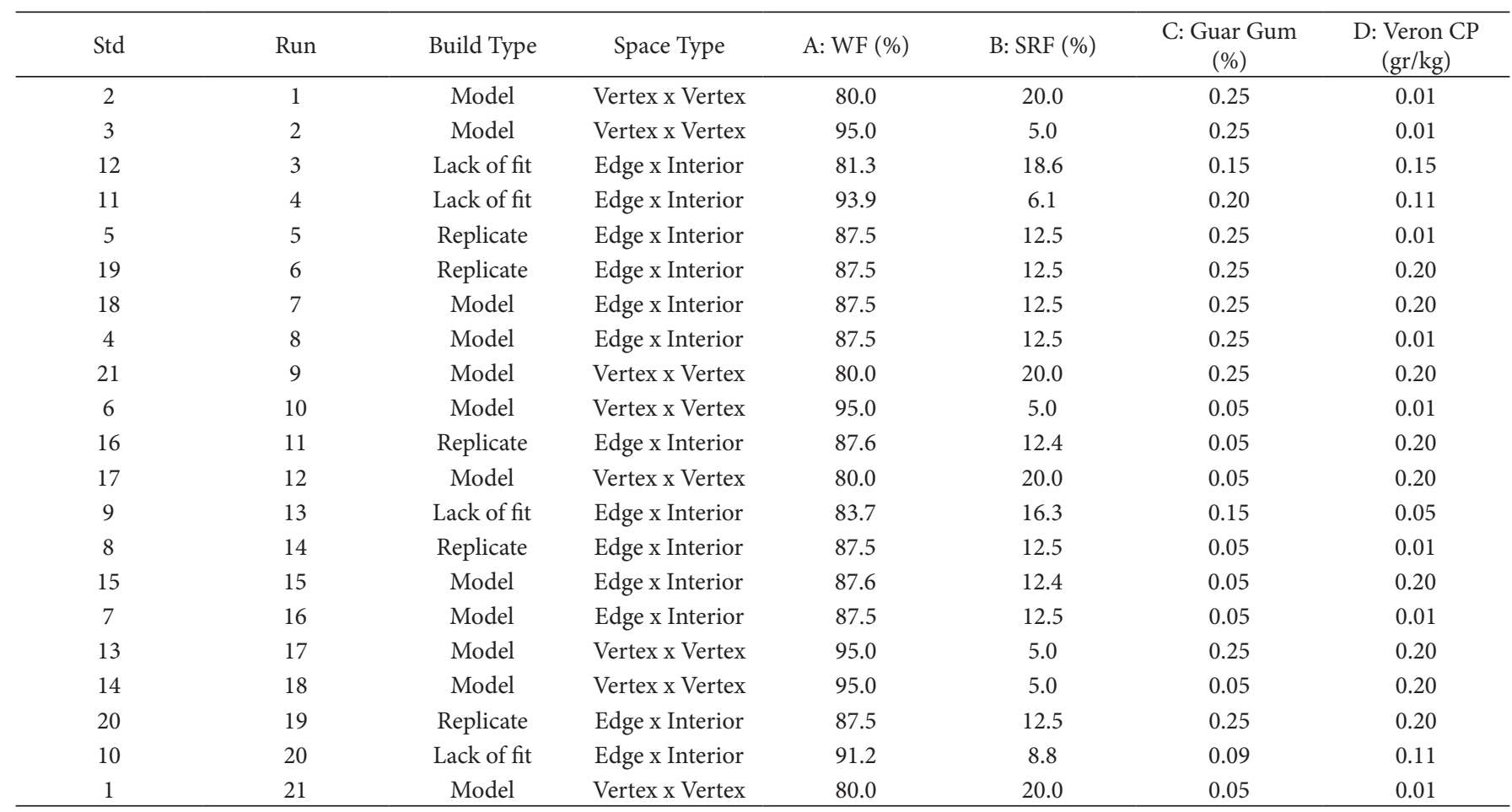

Std: standard order.

This technique uses desirability functions that allow measurement of different response variables on the same scale, and therefore, facilitate comparison between them. The desirability function assigns a score between 0 and 1, depending on the priorities of the overall objective. The optimal solution maximizes the overall desirability of each of the response variables (Myers et al., 2016).

\section{Bread production}

The basic formulation for bread production was: $100 \%$ wheat flour, $1 \%$ salt, $5 \%$ yeast, $5 \%$ butter, $10 \%$ sugar and $0.7 \%$ gluten vital. The amount of enzyme and guar gum were determined by the experimental design and amount of water added was determined by the Mixolab results.

For each formulation, the ingredients were mixed for 7 minutes to form the dough. Immediately after mixing, the dough was divided into portions of $420 \mathrm{~g}$, molded, resting in baking pans $(23 \times 9 \times 7 \mathrm{~cm})$ and fermented for 50 minutes in a fermentation camera at $38^{\circ} \mathrm{C}$ and $85 \% \mathrm{RH}$. Loaves were baked for 19 minutes in an electric oven (Prática, Brazil) at $170{ }^{\circ} \mathrm{C}$.

Through the simultaneous optimization technique, three different formulations were chosen. The quality characteristics were performed as well as sensory evaluation for these samples and for a control sample (bread without soursop flour, guar gum and enzymes).

\section{Sensory evaluation}

An affective test (appearance, taste, texture, smell, flavor, residual taste and overall liking) was performed as a complementary test on the three formulations optimized and on the control bread 24 hours after being baked to identify the acceptability of potential consumers on the different formulations. One hundred twelve panelists, between ages 18 to 24, participated in this study which was performed at the university's sensory laboratory. The panelists received each sample sequential monadically based on an order criterion which minimizes context and order effects (Wakeling \& MacFie, 1995). Samples were served in white plates randomly coded alphanumerically. All questions used a 9-point hedonic scale (with 1 = "disliked extremely", $5=$ "neither disliked or liked", $9=$ "liked extremely"), which is the most commonly used when testing consumer preference and acceptability regarding foods (Lim, 2011).

\section{Bread characterization}

Breads obtained were characterized by its specific volume (method 10-05.01; American Association of Cereal Chemists, 2009a), pH (method 02-52; American Association of Cereal Chemists, 2010), total ashes (method 08-01.01; American Association of Cereal Chemists, 2009b), and 4) moisture content (method, 44-15.02, American Association of Cereal Chemists, 2009c). All the tests were performed in duplicate.

\section{Statistical analysis}

The statistical analysis for the process mixture design was performed using Design Expert software version 11th. Analysis of variance (ANOVA) was carried out with $\alpha=5 \%$ significance level, assuring each of the ANOVA assumptions were satisfied, with a minimum $\mathrm{R}$-squared predicted coefficient of 0.6 , and a 
maximum difference between the R-squared adjusted coefficient and R-squared predicted of 0.2 .

The statistical analysis for the sensory evaluation test was performed in Minitab software version 17, using a Mix Model, where the presentation order and consumers were analyzed as blocking variables, and bread formulations as treatments. The results were evaluated using an ANOVA with a 5\% significance level. A Tukey Test was performed in order to determine the difference of the means for the bread characteristics measurements; the results were evaluated using a Tukey Test with a 5\% significance level.

\section{Results and discussion}

\subsection{Rheological characteristics}

The results for all the 21 mixes are shown in Table 2 for each of the Mixolab parameters. All the parameters were analyzed as response variables in the process mixture design, although not all of them showed significant models. Table 3 shows the mathematical models of the Mixolab parameters, as well as the
R-squares and p-values. Results indicated that ten of them were significant: Water absorption (WA), Dough Development Time (DDT), Stability, C2, C1-C2, C3, C2-C3, C4, C3-C4 and C5.

\subsection{Optimization}

Using the simultaneous optimization technique, three criteria were established: criterion 1: to maximize the percentage of SRF, criterion 2: to form a strong gluten network, and criterion 3: to form a weak gluten network. For having a strong gluten network dough development time, stability and C2 must be maximized, while C1-C2 (gluten network strength) must be minimized. Water absorption is a parameter that also evaluates the gluten formation network, but it was kept in range because for each formulation it varies according to the Mixolab results. Table 4 shows the results of the optimal formulation for each criterion.

To maximize the percentage of SRF, the formulation was: $80 \%$ WF, $20 \%$ SRF, $0.086 \%$ guar gum, $0.01 \mathrm{gr} / \mathrm{kg}$ of Veron CP enzyme and $79.6 \%$ water. For a strong gluten network, the formulation was $95 \%$ WF, 5\% SRF, $0.050 \%$ guar gum, $0.01 \mathrm{gr} / \mathrm{kg}$ of Veron CP

Table 2. Mixolab data results from the process mixture design.

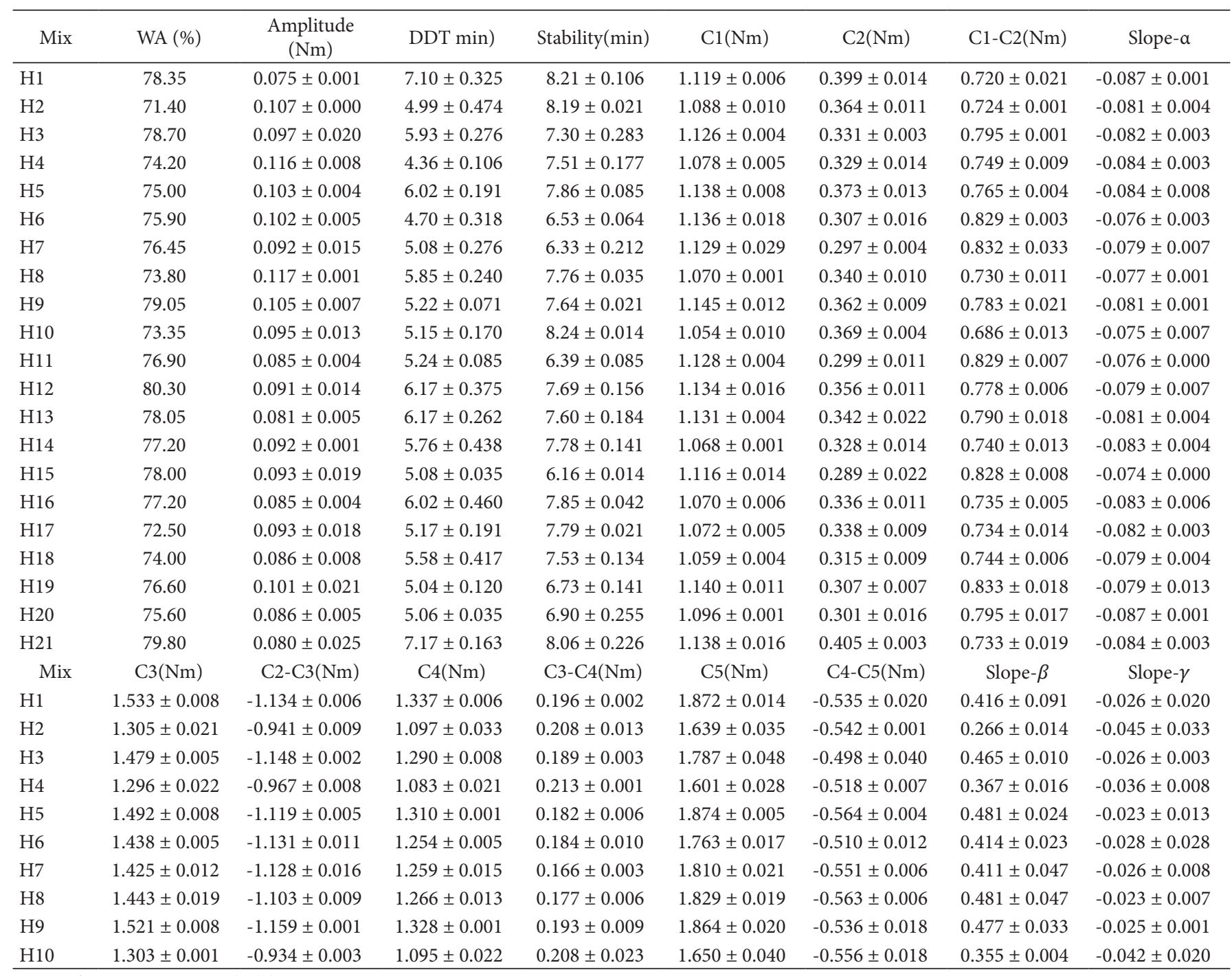

Means of two repetitions \pm standard deviation. 
Original Article

Saavedra et al.

Table 2. Continued...

\begin{tabular}{|c|c|c|c|c|c|c|c|c|}
\hline Mix & WA (\%) & $\begin{array}{c}\text { Amplitude } \\
(\mathrm{Nm})\end{array}$ & DDT min) & Stability(min) & $\mathrm{C} 1(\mathrm{Nm})$ & $\mathrm{C} 2(\mathrm{Nm})$ & $\mathrm{C} 1-\mathrm{C} 2(\mathrm{Nm})$ & Slope- $\alpha$ \\
\hline H11 & $1.430 \pm 0.018$ & $-1.131 \pm 0.006$ & $1.257 \pm 0.018$ & $0.173 \pm 0.000$ & $1.799 \pm 0.047$ & $-0.542 \pm 0.030$ & $0.412 \pm 0.074$ & $-0.017 \pm 0.004$ \\
\hline $\mathrm{H} 12$ & $1.468 \pm 0.026$ & $-1.112 \pm 0.037$ & $1.304 \pm 0.014$ & $0.164 \pm 0.040$ & $1.820 \pm 0.016$ & $-0.516 \pm 0.002$ & $0.420 \pm 0.011$ & $-0.038 \pm 0.003$ \\
\hline H14 & $1.445 \pm 0.017$ & $-1.117 \pm 0.003$ & $1.264 \pm 0.002$ & $0.182 \pm 0.019$ & $1.783 \pm 0.002$ & $-0.519 \pm 0.000$ & $0.444 \pm 0.051$ & $-0.028 \pm 0.011$ \\
\hline H15 & $1.430 \pm 0.007$ & $-1.142 \pm 0.015$ & $1.240 \pm 0.018$ & $0.19 \pm 0.0110$ & $1.781 \pm 0.025$ & $-0.541 \pm 0.007$ & $0.458 \pm 0.011$ & $-0.034 \pm 0.003$ \\
\hline H18 & $1.278 \pm 0.011$ & $-0.964 \pm 0.002$ & $1.039 \pm 0.018$ & $0.240 \pm 0.006$ & $1.568 \pm 0.021$ & $-0.530 \pm 0.004$ & $0.393 \pm 0.004$ & $-0.046 \pm 0.003$ \\
\hline H19 & $1.440 \pm 0.002$ & $-1.133 \pm 0.009$ & $1.267 \pm 0.003$ & $0.173 \pm 0.005$ & $1.829 \pm 0.008$ & $-0.562 \pm 0.011$ & $0.464 \pm 0.014$ & $-0.022 \pm 0.006$ \\
\hline $\mathrm{H} 20$ & $1.378 \pm 0.004$ & $-1.077 \pm 0.02$ & $1.172 \pm 0.016$ & $0.206 \pm 0.019$ & $1.696 \pm 0.013$ & $-0.524 \pm 0.003$ & $0.437 \pm 0.038$ & $-0.024 \pm 0.017$ \\
\hline $\mathrm{H} 21$ & $1.529 \pm 0.013$ & $-1.124 \pm 0.016$ & $1.339 \pm 0.011$ & $0.190 \pm 0.002$ & $1.894 \pm 0.024$ & $-0.555 \pm 0.013$ & $0.486 \pm 0.045$ & $-0.023 \pm 0.007$ \\
\hline
\end{tabular}

Means of two repetitions \pm standard deviation.

Table 3. Mathematical models for significant Mixolab parameters from the process mixture design (I-optimal).

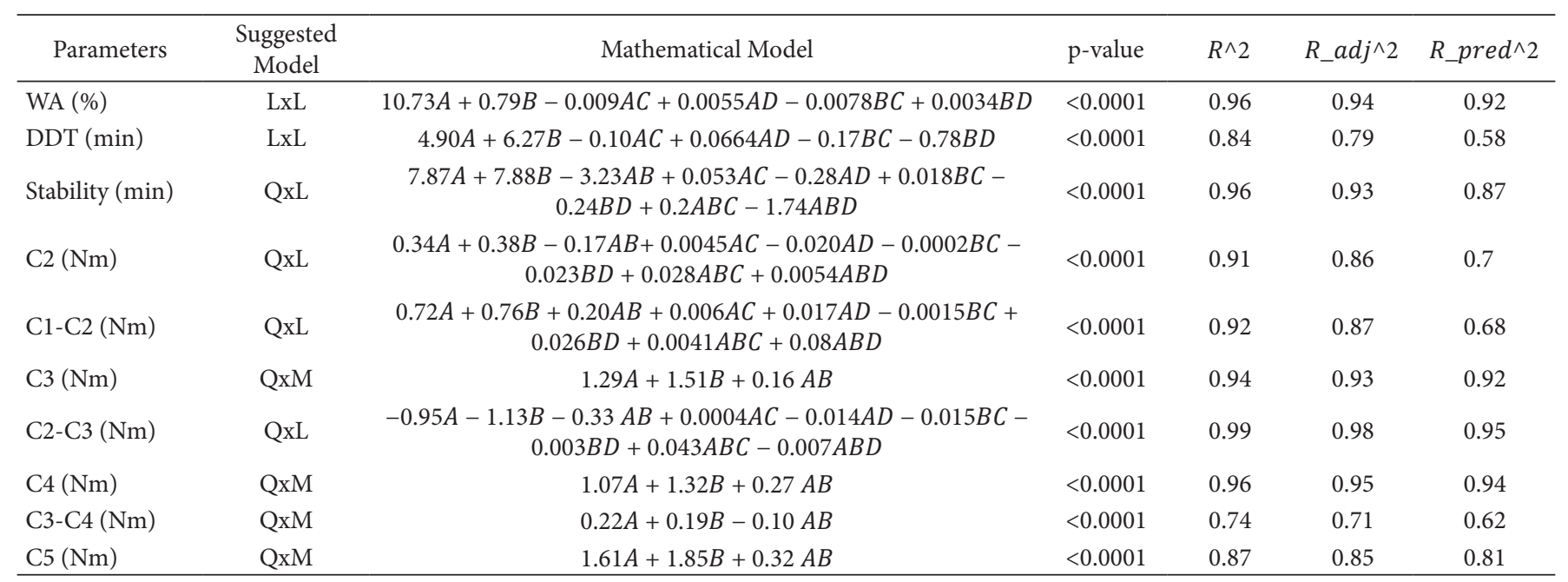

LxL: Linear x Linear; QxL: Quadratic x Linear; QxM: Quadratic x Mean.

Table 4. Results from the desirability function approach.

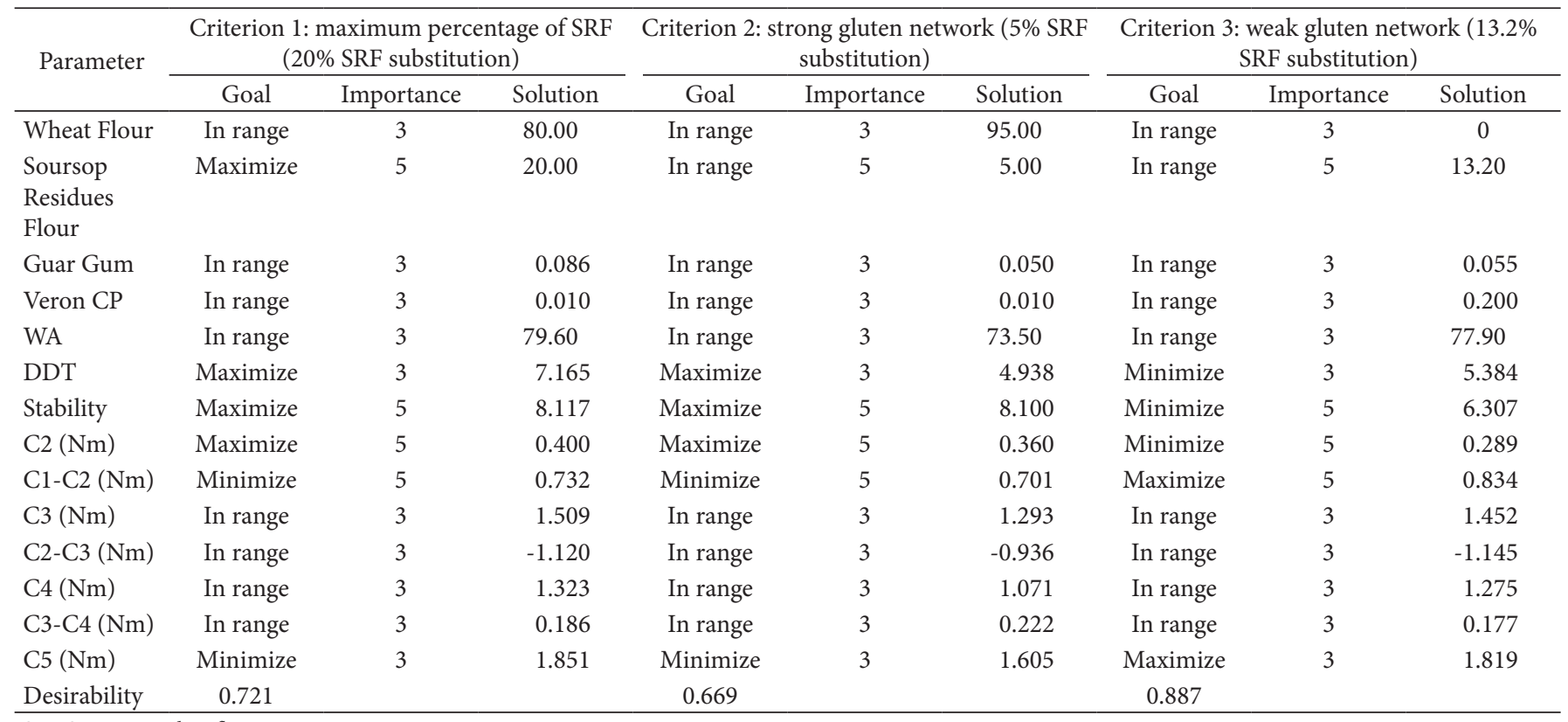

SRF: Soursop residues flour. 
enzyme and 73.5\% water, and finally for a weak gluten network, the formulation was $86.60 \% \mathrm{WF}, 13.2 \% \mathrm{SRF}, 0.055 \%$ guar gum, $0.2 \mathrm{gr} / \mathrm{kg}$ of Veron CP enzyme and $77.9 \%$ water. The remaining ingredients were left constant.

For the criterion of maximum percentage of SRF and a strong gluten network, both loaves showed that with more content of soursop residues flour, low levels of guar gum and Veron CP, more water absorption was needed. Even though there are not similar studies using soursop residues flour as substitute in wheat flour, studies in partial substitution with sources of dietary fiber, showed that an increase in content of a dietary fiber increases the water absorption (Schmiele et al., 2017; Peressini \& Sensidoni, 2009; Rosell et al., 2010). The dough development time ensures loaves of high volume and soft texture (Schmiele et al., 2017), in this case, with higher content of soursop residues flour, or dietary fiber, a higher dough development time was achieved. As the DDT obtained is 7.2 minutes, it is still suitable for baking (Schmiele et al., 2017). A study regarding the addition of dietary fiber into wheat flour as a flour substitution has shown the same results (Sirbu \& Arghire, 2017). Regarding the parameter C2, with more content of SRF the dough consistency increases to the maximum.

The parameter $\mathrm{C} 1-\mathrm{C} 2$, or protein network strength under heating, showed that it slightly decreases when the addition of SRF increases. In the study conducted by Schmiele et al. (2017), it was observed that a gluten protein dilution resulted in a weaker gluten network. The starch gelatinization increased when more content of SRF was added, while it decreased when it had less amount of SRF. The results shown for the parameter C2-C3 were the opposite: when more amount of SRF was added, the rate of the starch gelatinization decreased. This behavior repeated in parameters C4, C3-C4 and C5. For parameters C4 and C3-C4, this could be due to a lower starch hydrolysis and because SRF was more soluble in water (Schmiele et al., 2017). Also, a decrease in $\mathrm{C} 3-\mathrm{C} 4$ could be explained due to a minor activity of amylase with higher concentrations of SRF (Hadnađev et al., 2011). For the parameter C5 (starch retrogradation), it is mainly related with the staling of bread, therefore, the retardation of starch retrogradation is desirable in most food products. To determine effects on this parameter, deeper studies are needed regarding the interaction of different factors such as lipids, proteins and other food additives (Wang et al., 2015).

Bread formulations with higher fiber have less porosity (Tamba-Berehoiu et al., 2016) and a high interaction between the gluten network and the gelatinized starch; therefore, the more the substitution of SRF, the harder the texture and the higher the rupture force of the bread (Santiago et al., 2015). In general terms, most of the effects were caused due to the partial absence of gluten protein and high fiber content, which also results in a lower gas retention of dough (Santiago et al., 2015). For criterion 3 (weak gluten network), the individual goals for each response variable were the opposite to the ones in criterion 2 (strong gluten network); however, the water absorption parameter had the same behavior in both cases; it increased when adding SRF. For the rest of the response variables, the results showed that the behavior was the opposite, as with the previous criteria.

\subsection{Bread characteristics}

Regarding the moisture and total ash content, all loaves were statistically equal to the control bread, as shown in Table 5. In other words, the addition of soursop residues flour did not improve either the moisture or the ash contents.

The specific volume is an important characteristic when analyzing the quality of the breads (Mudgil et al., 2016). In regards to the specific volume of the loaves, they were statistically different (Table 5 and Figure 1). In spite of this, the loaf with a strong gluten network had the second-best result - the closest to the control bread, while the loaf with a maximum percentage of SRF presented the lowest value. Similar studies showed that fiber blends formulations and an increase of the water addition induced a reduction in the specific volume (Rosell \& Santos, 2010). In addition, results with lower specific volume were related to the reduced number of pores (common in high fiber products) and a higher interaction between the gelatinized starch and gluten network, which was also related with a less capacity of dough gas retention (Santiago et al., 2015). Other studies have also showed that the addition of products with more fiber, for example sweet potato flour or Andean blueberry pulp resulted in a reduction of specific volume (Guijarro-Fuertes et al., 2019; Franco et al., 2020).

The $\mathrm{pH}$ levels for the loaf with a strong gluten network was significantly different from the control bread. For the loaf with a maximum percentage of SRF and the loaf with a weak gluten network, the $\mathrm{pH}$ levels were similar, and both had the lowest $\mathrm{pH}$ content of all the formulations. Formulations with more substitution of SRF presented more acidic loaves, while the loaf with a strong gluten network had the same $\mathrm{pH}$ value as the control bread. The $\mathrm{pH}$ determination can provide essential information regarding the decomposition process (changes in nutritional value) and the conservation of the product (Ferreira et al., 2015). An increased amount of $\mathrm{pH}$ content within a product, can be related with a lower capacity of control of microorganism growth (Ferreira et al., 2015).

Table 5. Results from the bread characteristics measurements.

\begin{tabular}{lcccccccc}
\hline \multicolumn{1}{c}{ Characteristics } & \multicolumn{2}{c}{ Maximum percentage of SRF } & \multicolumn{2}{c}{ Strong gluten network } & \multicolumn{2}{c}{ Weak gluten network } & \multicolumn{2}{c}{ Control bread } \\
\hline $\begin{array}{l}\text { Total ashes (\%) } \\
\text { Specific }\end{array}$ & $0.049 \pm 0.0065$ & $\mathrm{~A}$ & $0.051 \pm 0.0017$ & $\mathrm{~A}$ & $0.0499 \pm 0.0009$ & $\mathrm{~A}$ & $0.0579 \pm 0.0011$ & $\mathrm{~A}$ \\
volume (mL/g) & $1.921 \pm 0.0274$ & $\mathrm{D}$ & $3.825 \pm 0.1125$ & $\mathrm{~B}$ & $3.0830 \pm 0.2690$ & $\mathrm{C}$ & $4.8250 \pm 0.2000$ & $\mathrm{~A}$ \\
$\mathrm{pH}$ & $4.590 \pm 0.0141$ & $\mathrm{C}$ & $5.130 \pm 0.0212$ & $\mathrm{~A} / \mathrm{B}$ & $4.7400 \pm 0.0141$ & $\mathrm{~B} / \mathrm{C}$ & $5.6100 \pm 0.2550$ & $\mathrm{~A}$ \\
Moisture (\%) & $0.067 \pm 0.0035$ & $\mathrm{~A}$ & $0.057 \pm 0.0008$ & $\mathrm{~A}$ & $0.0534 \pm 0.0110$ & $\mathrm{~A}$ & $0.0593 \pm 0.0024$ & $\mathrm{~A}$ \\
\hline
\end{tabular}

Formulations: Maximum percentage of SRF (20\% SRF substitution) Strong gluten network (5\% SRF), Weak gluten network (13.2\%), and Control bread (100\% wheat flour). Different letters in the same row are significantly different, Tukey Test $(\alpha=0.05)$. 


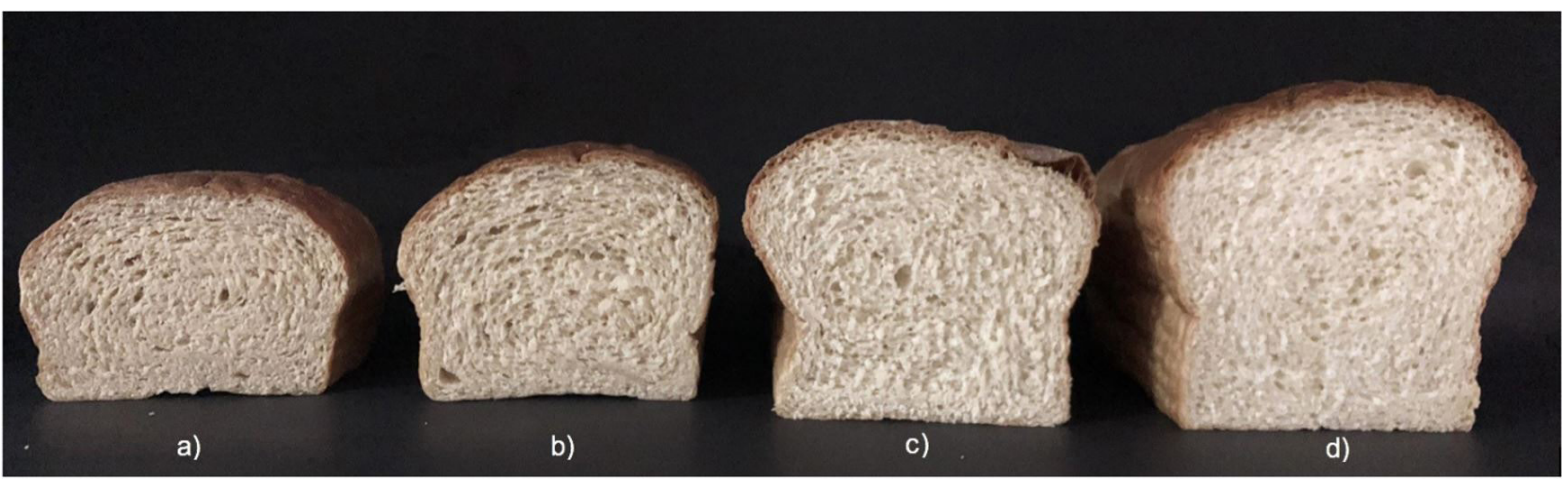

Figure 1. Point of view of the slice of the loaves, from left to right: (a) maximum percentage of SRF); (b) weak gluten network; (c) strong gluten network and (d) the control bread (100\% wheat flour bread).

\section{Sensorial evaluation}

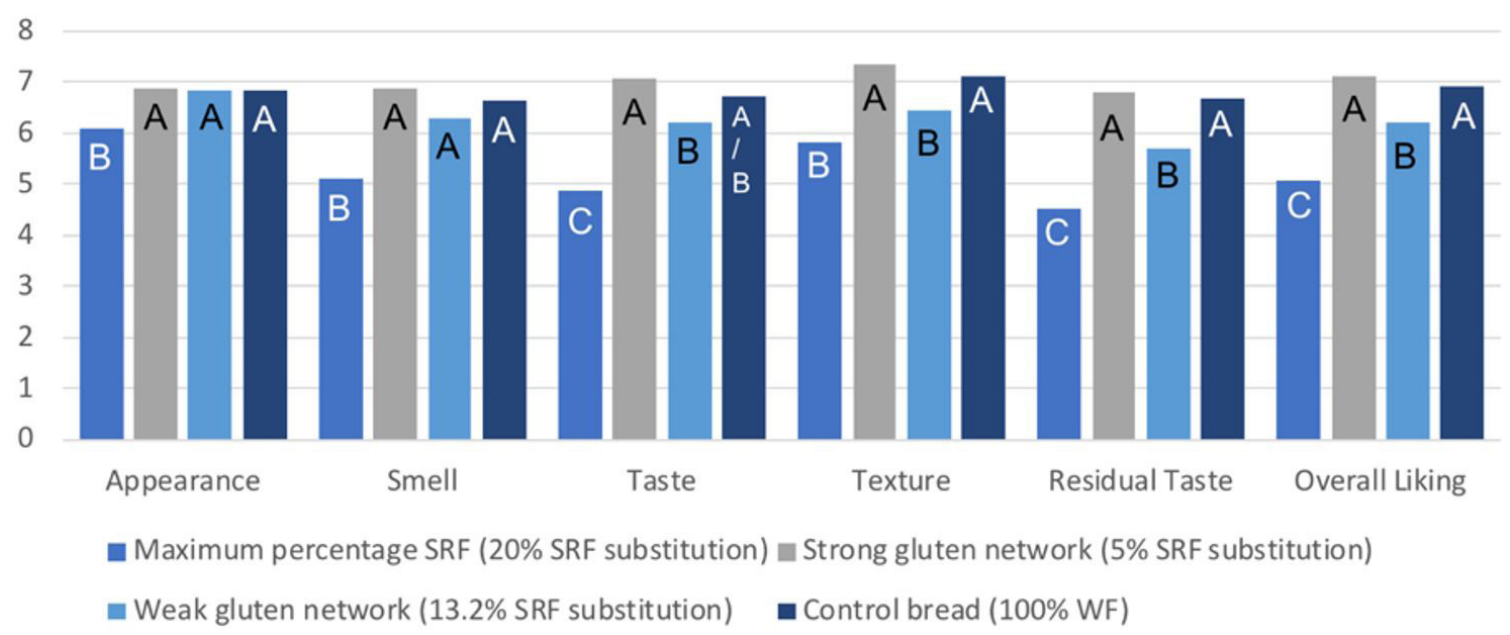

Figure 2. Sensorial evaluation results for each formulation. Different letters in the same row are significantly different, Tukey Test ( $\alpha=0.05)$.

\subsection{Sensory evaluation}

Results from the affective test are shown in Figure 2. Regarding to the appearance and smell attributes, statistically the loaves for criterion 2 (strong gluten network) and criterion 3 (weak gluten network) were equal to the control bread and had an average score of 6.85 ("Like Slightly") and 6.60 ("Like Slightly"), respectively. For the attributes: taste, texture and residual taste, the loaf of criterion 2 (strong gluten network) was statistically equal to the control bread. In the 9-point scale, the average scores for the sample of criterion 2 (strong gluten network) were: 7.08 ("Like Moderately"), 7.34 ("Like Moderately"), 6.80 ("Like Slightly"), respectively. Finally, for the overall liking, the loaf of criterion 2 (strong gluten network) was statistically equal to the control bread, having a 7.09 average score ("Like Moderately"), while the loaves of criterion 1 (maximum percentage of SRF) and criterion 3 (weak gluten network) were statistically different with each other and with the control bread.

For all the attributes, the loaf of criterion 1 (maximum percentage of SRF), which had more substitution of soursop (20\%), showed the lowest scores. According to the comments of the potential consumers, the sample had a strong bitter taste, bad texture and a strong residual taste and smell (resembling a rotten or decomposing fruit). The strong and bitter taste could be related to the sub acid flavor and distinctive aroma characteristics of the soursop (Leite et al., 2019). In addition, there is a negative medium strong correlation between the acidity level in bread and the specific volume of it (Semić et al., 2009). Therefore, the sour flavor of the dough and the flour (depending on the criteria) decreased mainly the $\mathrm{pH}$ value and specific volume. The more the percentage of substitution of SRF, the more the level of acidity in bread.

\section{Conclusions}

To conclude, the results showed that the loaf with a maximum percentage of SRF had an opposite behavior than a control bread, even when the characteristics were set to have a strong gluten network. The formulation with a strong gluten network had equal characteristics to a control bread, from which it can be concluded that criterion 2 with a 5\% SRF substitution does have a strong gluten network and the loaf with a weak gluten network had an opposite behavior as the control bread. From these results, it can be determined that a strong gluten network is related to good quality in loaves and with the use of Mixolab, 
the quality of the wheat flour partially replaced with the soursop residues flour was predicted.

From the affective test, bread with a strong gluten network was equal to a control bread in all six evaluated attributes. From this study, it can be concluded that a loaf of bread made with $20 \%$ of SRF substitution (maximum percentage of SRF) is not recommended due to its poor-quality characteristics and lower scores in the sensorial evaluation. This work recommends the use of soursop residues to produce flour to make bread with a $5 \%$ SRF substitution, giving a use to the wastes generated. The current work could be used for further research regarding the use of fruit residues in other functional products.

\section{Acknowledgements}

The authors would like to acknowledge Proalva (Ecuador) for the donation of the soursop residues. This work was supported by Universidad San Francisco de Quito USFQ through their program Collaboration Grants and the publication of this article was funded by the Academic Articles Publication Fund of Universidad San Francisco de Quito USFQ.

\section{References}

American Association of Cereal Chemists - AACC. (2009a). AACC method 10-05.01: guidelines for measurement of volume by rapeseed displacement. St. Paul: AACC. https://doi.org/10.1094/ AACCIntMethod-10-05.01.

American Association of Cereal Chemists - AACC. (2009b). AACC method 08-01.01: guidelines for measurement of total ash. St. Paul: AACC. Retrieved from http://methods.aaccnet.org/summaries/08-01-01.aspx

American Association of Cereal Chemists - AACC. (2009c). AACC method 44-15.02: guidelines for measurement of moisture: air oven methods. St. Paul: AACC. Retrieved from http://methods.aaccnet. org/summaries/44-15-02.aspx

American Association of Cereal Chemists - AACC. (2010). AACC method 02-52.01: guidelines for measurement of hydrogen-ion activity $(\mathrm{pH})$ : electrometric method. St. Paul: AACC. Retrieved from http:// methods.aaccnet.org/summaries/02-52-01.aspx

Badrie, N., \& Schauss, A. G. (2010). Soursop (Annona muricata L.): composition, nutritional value, medicinal uses, and toxicology. In R. Watson \& V. Preedy (Eds.), Bioactive foods in promoting health: probiotics and prebiotics (Chap. 39, pp. 621-643). Amsterdam: Academic Press. http://dx.doi.org/10.1016/B978-0-12-374628-3.00039-6.

Cauvain, S. (2015). Technology of breadmaking. Boston: Springer International Publishing. https://doi.org/10.1007/978-3-319-14687-4.

Cavalcante, R., Morgano, M., Glória, M., Rocha, M., Araújo, M., \& Moreira-Araújo, R. (2019). Mineral content, phenolic compounds and bioactive amines of cheese bread enriched with cowpea. Food Science and Technology, 39(4), 843-849. http://dx.doi.org/10.1590/ fst.11718.

Chaparro, S. P., Tavera, M. L., Martínez, J. J., \& Gil, J. H. (2014). Propiedades funcionales de la harina y de los aislados proteicos de la semilla de guanábana (Annona muricata). Revista Udca Actualidad \& Divulgacion Cientifica, 17(1), 151-159. http://dx.doi.org/10.31910/ rudca.v17.n1.2014.950.

Coria-Téllez, A. V., Montalvo-Gónzalez, E., Yahia, E. M., \& ObledoVázquez, E. N. (2018). Annona muricata: a comprehensive review on its traditional medicinal uses, phytochemicals, pharmacological activities, mechanisms of action and toxicity. Arabian Journal of Chemistry, 11(5), 662-691. http://dx.doi.org/10.1016/j.arabjc.2016.01.004.

Cornell, J. (2002). Experiments with mixtures: designs, models, and the analysis of mixture data (3rd ed.). New York: John Wiley \& Sons. http://dx.doi.org/10.1002/9781118204221.

Deng, G. F., Shen, C., Xu, X. R., Kuang, R. D., Guo, Y. J., Zeng, L. S., Gao, L. L., Lin, X., Xie, J. F., Xia, E. Q., Li, S., Wu, S., Chen, F., Ling, W. H., \& Li, H. B. (2012). Potential of fruit wastes as natural resources of bioactive compounds. International Journal of Molecular Sciences, 13(7), 8308-8323. http://dx.doi.org/10.3390/ijms13078308. PMid:22942704.

Dziki, D., Różyło, R., Gawlik-Dziki, U., \& Swieca, M. (2014). Current trends in the enhancement of antioxidant activity of wheat bread by the addition of plant materials rich in phenolic compounds. Trends in Food Science \& Technology, 40(1), 48-61. http://dx.doi. org/10.1016/j.tifs.2014.07.010.

Ferreira, M. S. L., Santos, M. C. P., Moro, T. M. A., Basto, G. J., Andrade, R. M. S., \& Gonçalves, É. C. B. A. (2015). Formulation and characterization of functional foods based on fruit and vegetable residue flour. Journal of Food Science and Technology, 52(2), 822830. http://dx.doi.org/10.1007/s13197-013-1061-4. PMid:25694690.

Franco, V. A., Garcia, L. G. C., \& Silva, F. A. (2020). Addition of hydrocolidics in gluten-free bread and replacement of rice flour for sweet potato flour. Food Science and Technology, 40(Suppl. 1), 88-96. http://dx.doi.org/10.1590/fst.05919.

Guijarro-Fuertes, M., Andrade-Cuvi, M. J., Bravo-Vásquez, J., RamosGuerrero, L., \& Vernaza, M. G. (2019). Andean blueberry (Vaccinium floribundum) bread: physicochemical properties and bioaccessibility of antioxidants. Food Science and Technology, 39(Suppl. 1), 56-62. http://dx.doi.org/10.1590/fst.30317.

Guimarães, J. T., Silva, E. K., Ranadheera, C. S., Moraes, J., Raices, R. S., Silva, M. C., Ferreira, M. S., Freitas, M. Q., Meireles, M. A. A., \& Cruz, A. G. (2019). Effect of high-intensity ultrasound on the nutritional profile and volatile compounds of a prebiotic soursop whey beverage. Ultrasonics Sonochemistry, 55, 157-164. http://dx.doi. org/10.1016/j.ultsonch.2019.02.025. PMid:30853535.

Hadnađev, T. D., Torbica, A., \& Hadnađev, M. (2011). Rheological properties of wheat flour substitutes/alternative crops assessed by Mixolab. Procedia Food Science, 1, 328-334. http://dx.doi.org/10.1016/j. profoo.2011.09.051.

Homkhiew, C., Ratanawilai, T., \& Thongruang, W. (2014). The optimal formulation of recycled polypropylene/rubberwood flour composites from experiments with mixture design. Composites. Part B, Engineering, 56, 350-357. http://dx.doi.org/10.1016/j.compositesb.2013.08.041.

Ibrahim, U. K., Salleh, R. M., \& Maqsood-ul-Haque, S. N. S. (2015). Bread towards functional food: an overview. International Journal of Food Engineering, 1(1), 39-43.

Instituto Nacional de Estadísticas y Censos - INEC. (2014). Estadística de información ambiental económica en gobiernos autónomos descentralizados municipales 2014. Retrieved from http://www. ecuadorencifras.gob.ec/documentos/web-inec/Encuestas_Ambientales/ Municipios_ConsProvinciales_2014/Municipios-2014/201412_ GADS\%20MunicipalesDocumentoTecnicoDeResultados.pdf

Instituto Nacional de Investigaciones Agropecuarias - INIAP. (2014). Guanábana. Retrieved from http://tecnologia.iniap.gob.ec/index. php/explore-2/mfruti/rguanabana

Kouassi-Koffi, J. D., Sturza, A., Păucean, A., Man, S., Mureșan, A. E., Petruț, G., Mureșan, V., \& Muste, S. (2019). Effect of glucose oxidase addition on the textural characteristics of wheat-maize dough and bread. Food Science and Technology, 39(1), 127-133. http://dx.doi. org/10.1590/fst.27117. 
Lee, W. Z., Chang, S. K., Khoo, H. E., Sia, C. M., \& Yim, H. S. (2016). Influence of different extraction conditions on antioxidant properties of soursop peel. Acta Scientiarum Polonorum. Technologia Alimentaria, 15(4), 419-428. http://dx.doi.org/10.17306/J.AFS.2016.4.40. PMid:28071019.

Leite, M. T. S. Na., Jesus, M. S., Silva, J. L. A., Araujo, H. C. S., Sandes, R. D. D., Shanmugam, S., \& Narain, N. (2019). Effect of spray drying on bioactive and volatile compounds in soursop (Annona muricata) fruit pulp. Food Research International, 124, 70-77. http://dx.doi. org/10.1016/j.foodres.2018.09.039. PMid:31466652.

Lim, J. (2011). Hedonic scaling: a review of methods and theory. Food Quality and Preference, 22(8), 733-747. http://dx.doi.org/10.1016/j. foodqual.2011.05.008.

Mudgil, D., Barak, S., \& Khatkar, B. S. (2014). Guar gum: processing, properties and food applications. A review. Journal of Food Science and Technology, 51(3), 409-418. http://dx.doi.org/10.1007/s13197011-0522-x. PMid:24587515.

Mudgil, D., Barak, S., \& Khatkar, B. S. (2016). Optimization of bread firmness, specific loaf volume and sensory acceptability of bread with soluble fiber and different water levels. Journal of Cereal Science, 70, 186-191. http://dx.doi.org/10.1016/j.jcs.2016.06.009.

Myers, R., Montgomery, D., \& Anderson-Cook, C. (2016). Response surface methodology: process and product optimization using designed experiments (4th ed.). Hoboken: John Wiley \& Sons. https://doi. org/10.1017/CBO9781107415324.004

Peressini, D., \& Sensidoni, A. (2009). Effect of soluble dietary fibre addition on rheological and breadmaking properties of wheat doughs. Journal of Cereal Science, 49(2), 190-201. http://dx.doi. org/10.1016/j.jcs.2008.09.007.

Ramírez, A., \& De Delahaye, E. P. (2009). Propiedades funcionales de harinas altas en fibra dietética obtenidas de piña, guayaba y guanábana. Interciencia, 34(4), 293-298.

Rosell, C. M., \& Santos, E. (2010). Impact of fibers on physical characteristics of fresh and staled bake off bread. Journal of Food Engineering, 98(2), 273-281. http://dx.doi.org/10.1016/j.jfoodeng.2010.01.008.

Rosell, C. M., Santos, E., \& Collar, C. (2010). Physical characterization of fiber-enriched bread doughs by dual mixing and temperature constraint using the Mixolab ${ }^{\star}$. European Food Research and Technology, 231(4), 535-544. http://dx.doi.org/10.1007/s00217-010-1310-y.

Santiago, M., Matsushita, K., Tsuboi, K., Yamada, D., Murayama, D., Kawakami, S., Shimada, K., Koaze, H., \& Yamauchi, H. (2015). Texture and structure bread supplemented with purple sweet potato powder and treated with enzymes. Food Science and Technology Research, 21(4), 537-548. http://dx.doi.org/10.3136/fstr.21.537.

Schmiele, M., Ferrari Felisberto, M. H., Pedrosa Silva Clerici, M. T., \& Chang, Y. K. (2017). Mixolab ${ }^{\mathrm{TM}}$ for rheological evaluation of wheat flour partially replaced by soy protein hydrolysate and fructooligosaccharides for bread production. Lebensmittel-Wissenschaft + Technologie, 76, 259-269. http://dx.doi.org/10.1016/j.lwt.2016.07.014.

Semić, A., Oručević, S., Bauman, I., Muminović, Š., \& Klepo, B. (2009). Effects of increasing sourness of bread dough on bread quality. In 5th International Congress FLOUR-BREAD '09 and 7th Croation Congress of Cereal Technologists. Croatia. Retrieved from https:// bib.irb.hr/datoteka/479435.416_semic.pdf

Sirbu, A., \& Arghire, C. (2017). Functional bread: Effect of inulin-type products addition on dough rheology and bread quality. Journal of Cereal Science, 75, 220-227. http://dx.doi.org/10.1016/j.jcs.2017.03.029.

Solís-Fuentes, J. A., Hernández-Medel, M. del R., \& Durán-de-Bazúa, M. del C. (2011). Soursop (Annona muricata L.) seeds, therapeutic and possible food potential. In V. R. Preedy, R. R. Watson \& V. B. Patel (Eds.), Nuts and seeds in health and disease prevention (pp. 1045-1052). London: Academic Press. https://doi.org/10.1016/ B978-0-12-375688-6.10124-0.

Tamba-Berehoiu, R. M., Popa, C. N., Simion, V., \& Nedelcu, B. S. (2016). Comparative analysis on the quality of several breads assortments available on the Romanian market and on the technological processes reliability. Scientific Papers. Series Management, Economic, Engineering in Agriculture and Rural Development, 16(4), 361-368.

Tasiguano, B. L., Villarreal, C., Schmiele, M., \& Vernaza, M. G. (2019). Efecto del tiempo de cocción del zapallo (Cucurbita maxima) y la adición de glucosa oxidasa en el aumento de almidón resistente del pan de molde. Información Tecnológica, 30(3), 167-178. http:// dx.doi.org/10.4067/S0718-07642019000300167.

U.S. Department of Agriculture - USDA. (2019). Soursop, raw. Retrieved from https://fdc.nal.usda.gov/fdc-app.html\#/food-details/167761/ nutrients

United Nations. (2020). International Day of Awareness on Food Loss and Waste reduction 29 september. Retrieved from https://www. un.org/en/observances/end-food-waste-day

Villela, P., Batista, Â. G., \& Dessimoni-Pinto, N. A. V. (2013). Nutritional composition of Annona crassiflora pulp and acceptability of bakery products prepared with its flour. Food Science and Technology, 33(3), 417-423. http://dx.doi.org/10.1590/S0101-20612013005000082.

Wakeling, I. N., \& MacFie, H. (1995). Designing consumer trials balanced for first and higher orders of carry-over effect when only a subset of $\mathrm{k}$ samples from t may be tested. Food Quality and Preference, 6(4), 299-308. http://dx.doi.org/10.1016/0950-3293(95)00032-1.

Wang, S., Li, C., Copeland, L., Niu, Q., \& Wang, S. (2015). Starch retrogradation: a comprehensive review. Comprehensive Reviews in Food Science and Food Safety, 14(5), 568-585. http://dx.doi. org/10.1111/1541-4337.12143. 